\title{
Ensaio de épocas de plantio sobre várias características agronômicas na cultura de soja (Glycinemax (L.) Merrill), variedades "Júpiter", "Prata", "Oriente" e "Pelicano", em Aripuanà-MT
}

\author{
Kaoru Yuyama $\left({ }^{*}\right)$
}

\begin{abstract}
Resumo
Quatro épocas de plantio, espaçadas de $15 \mathrm{em} 15$ dias, iniciando-se em 04 de dezembro, foram utilizadas num ensaio de campo instalado no Campo Experimental do INPA-Aripuanã, com o objetivo de estudar os efeitos das épocas de plantio sobre várias características agronômicas das variedades de soja Júpiter, Prata, Oriente e Pelicano, durante o ano agrícola de 1976/77. 0 delineamento experimental utilizado foi o de parcelas subdivididas em blocos ao acaso, com quatro repetiçóes, sendo as épocas consideradas como parcelas e as variedades como subparcelas. Os resultados obtidos mostram que: com um atraso no plantio, há uma diminuição de ciclo da planta, seja no período vegetativo seja no reprodutivo (com exceção das variedades Júpiter e Prata), sendo isto uma conseqüência do fotoperíodo; com a diminuiçăo do ciclo da planta, houve uma diminuiçăo na altura final das plantas, diâmetro do cauice, número de vagens por planta e aumento da altura de inserção da $1 .^{\circ}$ vagem. A variedade Júpiter mostrou-se resistente à pústula bacteriana (Xanthomonas phaseoli var. sojensis). A melhor época de plantio foi a de dezembro, sendo a produção média de: $2.795,83$ $\mathrm{kg}=$ Oriente; $2.245,83 \mathrm{~kg}=$ Júpiter; $1.733,33 \mathrm{~kg}=$ Pelicano e $1.145,08 \mathrm{~kg}=$ Prata, por hectare Recomenda-se, para o plantio de soja na região de Aripuanã-MT, a variedade Oriente, no mês de dezembro e variedade Júpiter no mês do aezembro e $1 .{ }^{a}$ quinzena de janeiro. Como este ensaio é pioneiro nesta regiăo tropical, a época de plantio escolhida foi baseada na condição climática da região, com variedades de regiões menos sensíveis ao fotoperíodo.
\end{abstract}

\section{INTRODUÇÃo}

A soja, originária da China, foi introduzida no Brasil no século XIX, e é atualmente uma das culturas mais importantes do país. A soja contém em média $40 \%$ de proteína de alta qualidade e $21 \%$ de óleo, sendo ainda rica em cálcio, fóstoro, ferro e vitaminas como, Tiamina, Riboflavina e Niacina (Cowan, 1973; Litzemberger, 1974). Cada $100 \mathrm{~kg}$ de soja produz $18,5 \mathrm{~kg}$ de óleo e $78,9 \mathrm{~kg}$ de torta (Soybean Magic).
A soja, considerada como cultura de clima temperado, expandiu-se rapidamente ná região sul do país como o Rio Grande do Sul. Paraná e São Paulo, que compõem a região da cultura tradicional. A região de expansão é de fundamental importância na determinação da viabilidade econômica social para estabelecimento da cuitura de soja, na região do Cerrado do Brasil Central e parte de Mato Grosso, Minas Gerais e Goiás. Na Amazônia, no Instituto Nacional de Pesquisa da Amazônia - INPA, no Setor de Leguminosas, iniciaram-se as pesquisas de soja, obtendo-se resultados satisfatórios. A utilização de técnicas de custo reduzido, como variedades melhoradas, espaçamento e densidade adequadas, utilização de fertilizantes de maneira econômica e plantio na época certa, aumentaram o retorno econômico da cultura. Como no caso de épocas de plantio, cada região difere da outra, isto é, cada meio ambiente tem sua época ideal de plantio. De um modo geral, nos Estados Unidos as maiores produções são obtidas com plantios feitos em início de maio (Feaster, 1949; Hartwig, 1954; Oster \& Cartter, 1954), porém, em latitude mais ao Norte, o plantio feito em fins de maio é o que traz as maiores produções (Torrie \& Briggs, 1955). Feaster (1949) e Osler \& Catter (1954) mostraram que, para produções ótimas, deve atrasar-se o plantio de variedades precoces em diferentes épocas; porém Torrie \& Briggs (1956) verificaram que a produção de variedades tardias, diminui, com piantio depois de 20 de maio.

No Estado de Minas Gerais, em latitudes semelhantes às do Espírito Santo, trabalhos realizados por Athow \& Swearingin (1968) Bueno, et al. (1975) Rios, et al. (1971) e Sediyama, et al. (1971) demonstraram ser o mês de novembro o período ideal para o plantio desta leguminosa.

$\left({ }^{\circ}\right)$ - Instituto Nacional de Pesquisas da Amazônia, Núcleo Aripuanã - MT 
Sediyama et al. (1973) recomendam,, para - Estado do Espírito Santo, nas regióes de São Mateus e Conceição da Barra, o plantio entre 15 de novembro e 5 de dezembro e, para as demais regiōes, durante o mês de novembro. Ainda no Estado do Espírito Santo, Milanez et al. (1978) comprovaram que a melhor época de plantio na região de Viana foi no período de 19 de novembro a 19 de dezembro e de Linhares de 20 de novembro a 26 de dezembro.

Para o Estado de São Paulo, Vernetti (1956) afirma que a soja pode ser plantada desde a segunda quinzena de setembro, sendo outubro a época ideal; entretanto Miyasaka (1965) verificou que a melhor época de plantio era primeira quinzena de novembro, a boa produção condicionada ao comprimento do dia, temperatura e umidade do solo de cada região. Na região de Alta Mogiana, Yuyama (1976) verificou que a melhor época de plantio foi a de 30 de outubro, utilizando duas variedades tardias Santa Rosa e Viçoja, sendo que para a variedade Santa Rosa recomenda o plantio de 20 de outubro a 30 de novembro sem alteração significativa na produtividade; para a variedade Viçoja o melhor plantio é a 30 de outubro.

Santos \& Pignataro (1971) na Região de Santa Maria, obtiveram a melhor produção com plantio em novembro para a variedade Yellow e Hardee; para as variedades Santa Rosa, Delta, Majos, Serrana, Pelicano, Acadian e
Mammoth em outubro; e Halle 7 em dezembro. Os plantios tardios diminuem o peso de 100 sementes e melhoram a quantidade de sementes.

Souza (1973), na região de Guaíba, determinou que as variedades Hardee e Bragg apresentaram melhores rendimeritos no plantio feito em 30 de outubro e 25 de novembro; o desenvolvimento das plantas diminui com retardamento da época de plantio assim como o ciclo da cultura.

O presente trabalho tem por objetivo determinar a melhor época de plantio para a região de Aripuanã-MT, visando à produção de grãos, adaptabilidade da cultura, possibilidade de mecanização e qualidade da semente.

\section{MATERIAIS E MÉTODOS}

Um ensaio de campo foi instalado nos terrenos do Campo Experimental do Núcleo de de Pesquisas de Humboldt (INPA - Aripuanã), no ano agrícola de 1976/77 em Aripuanã-MT (latitude $10^{\circ} 10^{\prime} \mathrm{S}$, longitude $57^{\circ} 27^{\prime} \mathrm{W}$ e altitude $203 \mathrm{~m}$ ). A análise de solo feita pelo Departamento de Solos da EMBRAPA-Manaus, mostrou :

\begin{tabular}{|c|c|c|c|c|c|}
\hline & & $\mathrm{P}$ & $\mathrm{Ca} \pm^{2}+\mathrm{Mg} \pm^{2}$ & $\mathrm{~K}$ & \\
\hline $\mathrm{pH}$ & $\mathrm{C} \%$ & p.p.m. & $m \cdot e \%$ & $\mathrm{ug} / \mathrm{ml}$ TFSA & $\mathrm{Al}+3$ \\
\hline 4,8 & 1,8 & 1.5 & 1,5 & $80\left({ }^{\star}\right)$ & 0.4 \\
\hline
\end{tabular}

As variedades utilizadas apresentaram as seguintes características:

\begin{tabular}{|c|c|c|c|c|}
\hline \multirow[t]{2}{*}{ CARACTERISTICAS } & \multicolumn{2}{|c|}{ VARIEDADES } & \multirow[b]{2}{*}{ ORIENTE (") } & \multirow[b]{2}{*}{ PELICANO } \\
\hline & JÚPITER & PRATA & & \\
\hline Tipo de crescimento & Determinado & Determinado & Determinado & Determinado \\
\hline Cor da pubescência & Castanha & Castanha & Castanha & Castanha \\
\hline Cor da semente & $\begin{array}{l}\text { Amar. esver- } \\
\text { deado ou Amar. }\end{array}$ & Amarela & Amarela & Amarela \\
\hline Cor do hilo & Castanha & Castanha & Castanha & Preta \\
\hline Teor de óleo da semente (\%) & 25,3 & $\rightarrow$ & 20,4 & 24,1 \\
\hline Teor de proteína da semente $(\%)$ & 43,6 & - & 49,4 & 45,7 \\
\hline Local da introdução & INTSOY-USA & IAPAR-PR & MANAUS-AM & INTSOY-USA \\
\hline
\end{tabular}

(*) - Variedade obtida de uma família japonesa em Manaus-AM.

As variedades Júpiter e Pelicano são resistentes à pústula bacteriana (Xanthomonas phaseoli var. sojensis). 
O experimento foi instalado em 04 de dezembro, semeando-se a espaço de $15 \mathrm{em} 15$ dias, num total de quatro épocas, sendo cada época com quatro variedades e quatro repetições.

O delineamento experimental foi de parcelas subdivididas em blocos ao acaso, sendo que a parcela experimental era constituída de quatro linhas de 5 metros de comprimento espaçadas de 0,60 metro, com 30 sementes por metro linear, considerando como parcela útil as duas linhas centrais.

O calcáreo foi aplicado na base de 2 toneladias por hectare, a lanço, no dia 02 de dezembro de 1976, aplicando-se no sulco, $180 \mathrm{~kg}$ de cloreto de potássio por hectare, no mesmo dia do plantio. As sementes foram previamente inoculadas com misto da TURFAL.

A germinação, de modo geral, ocorreu. após 4 a 5 dias do plantio, sendo satisfatória: após uma semana foi feito o desbaste.

Os dados sobre a data de florescimento foram tomados quando $50 \%$ das plantas estavam florescendo; os dados sobre a maturação foram tomados quando $95 \%$ das vagens estavam maduras, sendo ambos expressos em dias, após a germinação, e a colheita foi feita. conforme os dias de maturação dos tratamentos, colhendo-se manualmente as plantas das duas linhas centrais de cada parcela. No cam. po, foi tomado o grau de acamamento das plantas. De cada parcela foram tomadas 10 plantas, ao acaso, e foram obtidos os dados sobre a altura total das plantas, altura da inserçäo da primeira vagem, expressos em cen tímetros, o diâmetro do caule expresso em milímetros, número de vagens por planta; ainda foram tomados dados sobre "stand" final das plantas por parcela. O beneficiamento foi feito manualmente; determinou-se a produçăo por parcela em Kg/ha e a seguir, peso de 100 sementes, expresso em gramas. Foram observados ainda o grau de infestação da mancha púrpura (Cercospora kikuchii) e o grau de sementes estragadas.

Para fins de análise de variância, foi utilizado o Programa ANOVAR (Análise de Variância Fatorial Orotogonal Hierárquica) com teste F, no Setor de Serviços de Processamento de Dados do INPA. Para comparação de médias, foi utilizadio o teste de Tukey, com probabilidade de $5 \%$.

Durante o transcorrer do experimento no campo, os parâmetros climatológicos de precipitação, temperatura, ciclo da planta (época de plantio) e fotoperíodos variaram segundo a Fig. 1.

\section{Resultados E Discussões}

O Cuadro I mostra a análise de variância, valores de $\mathrm{F}$ e de várias características agronômicas analisadas. Nos dados dos Quadro II até Quadro XII. foi aplicado o teste de Tukey (ao nível de $5 \%$ ), nas comparações de médias entre as épocas, variedades e interação época $x$ variedades, respectivamente das várias características agronômicas analisadas. As Figuras de 2 a 10 mosiram variação de diversas características agronômicas com efeitos de variedade e épocas de plantio.

\section{"STAND" FINAL DAS PLANTAS}

Não houve diferenças quanto a "stand" final das plantas por parcela, indicando que esta característica não influenciou na variação encontrada em outras características estudadas, ou seja, todas as parcelas apresentaram uma competição igual de plantas dentro de cada fileira de plantio.

\section{FLORAÇÃo E MATURAÇÃó}

A floração é induzida principalmente pelo fotoperiodo. A soja apresenta sensibilidade ao fotoperiodismo, tanto que, quando semeada em época inadequada poderá ter sua produçāo reduzida, bem como apresentar grãos de qualidade inferior e características agronômicas não desejáveis na planta. Ainda as temperaturas do ar e do solo, as precipitações pluviais e a fertilidade do solo influenciam o bom desempenho da cultura (Camper \& Smith, 1958; Hartwig, 1954)

O Garner \& Allard, (1930) descobriram que com os fotoperiodos de $9.1 / 2$ a $12 \mathrm{hs}$. as plantas de soja florescem, aproximadamente, 25 dias após a germinação. Quando o fotoperíodo excede de 12 horas, resulta um aumento do pe- 
QUADRO I - Fonte de variação de F, obtidos nas análises de variância de vários caracteres agronômicos.

\begin{tabular}{|c|c|c|c|c|c|c|c|c|c|c|c|c|}
\hline Fonte de variação & $\begin{array}{c}\text { Produção } \\
\mathrm{Kg} / \mathrm{ha}\end{array}$ & $\begin{array}{c}\text { Floração } \\
(50 \%)\end{array}$ & $\begin{array}{c}\text { Maturaçăo } \\
(95 \%)\end{array}$ & $\begin{array}{c}\text { Altura das } \\
\text { plantas } \\
(\mathrm{CM})\end{array}$ & $\begin{array}{l}\text { Altura da } \\
\text { inserçăo } \\
\text { da 1.a va- } \\
\text { gem }(\mathrm{cm})\end{array}$ & $\begin{array}{c}\text { Diâmetro } \\
\text { do caule } \\
(\mathrm{mm})\end{array}$ & $\begin{array}{l}\text { N.o de va- } \\
\text { gens por } \\
\text { planta }\end{array}$ & $\begin{array}{c}\text { Peso } 100 \\
\text { sementes } \\
\text { (a) }\end{array}$ & $\begin{array}{c}\text { Stand das } \\
\text { plantas }\end{array}$ & $\begin{array}{l}\text { Acama- } \\
\text { mento }\end{array}$ & $\begin{array}{c}\text { Mancha } \\
\text { púrpura } \\
(\%)\end{array}$ & $\begin{array}{l}\text { Sementes } \\
\text { estraga- } \\
\text { das }(\%)\end{array}$ \\
\hline VARIEDADE(V) & $22,95^{\circ \cdots}$ & $1319,19^{\cdots} \bullet$ & $24710,84^{* * *}$ & $579,48^{* \cdots *}$ & $43,79^{\ldots \cdots}$ & $76,95^{\cdots \cdots}$ & $97,00^{\cdots}$ & $24,18^{* \ldots}$ & $2,21 \mathrm{~ns}$ & $18,00^{\cdots} \cdots$ & $4,98^{* *}$ & $1.84 \mathrm{~ns}$ \\
\hline ÉPOCAS(E) & $23,96^{*} \cdot$ & $138,06^{* \cdots}$ & $6703,62^{* * *}$ & $39,32^{* * *}$ & $22,13^{\ldots \cdots}$ & $76,56^{* * *}$ & $66,07^{* \cdots *}$ & $3,59^{\circ}$ & $0,44 \mathrm{~ns}$ & $2,25 \mathrm{~ns}$ & $2,04 \mathrm{~ns}$ & $4,49^{\circ}$ \\
\hline REPETIÇĀO(R) & $1,01 \mathrm{~ns}$ & $1,61 \mathrm{~ns}$ & $2,23 \mathrm{~ns}$ & $0,90 \mathrm{~ns}$ & $0,25 \mathrm{~ns}$ & $2,00 \mathrm{~ns}$ & $1.92 \mathrm{~ns}$ & $0.23 \mathrm{~ns}$ & 0,67 ns & $0,75 \mathrm{~ns}$ & $1,78 \mathrm{~ns}$ & $0,30 \mathrm{~ns}$ \\
\hline (V) $\times$ (E) & $4,90^{\cdots} \cdots$ & $25,78^{* \ldots *}$ & $948,42^{* * *}$ & $8,62^{* * *}$ & $3,73^{* \bullet}$ & $5,89^{* \cdots *}$ & $16,83^{* * *}$ & $123 \mathrm{~ns}$ & $1,09 \mathrm{~ns}$ & $225^{\circ}$ & $1,22 \mathrm{~ns}$ & $6,34 \cdots$ \\
\hline (V) $\times(\mathrm{R})$ & $0,45 \mathrm{~ns}$ & $1,06 \mathrm{~ns}$ & $1,87 \mathrm{~ns}$ & $1,16 \mathrm{~ns}$ & $0,97 \mathrm{~ns}$ & 0.84 ns & 0,92 ns & $1,64 \mathrm{~ns}$ & $0,75 \mathrm{~ns}$ & $0,75 \mathrm{~ns}$ & $1.55 \mathrm{~ns}$ & $0.78 \mathrm{~ns}$ \\
\hline (E) $X(R)$ & $1,40 \mathrm{~ns}$ & $0,31 \mathrm{~ns}$ & $1,73 \mathrm{~ns}$ & $0,94 \mathrm{~ns}$ & $0,46 \mathrm{~ns}$ & $0,94 \mathrm{~ns}$ & $1,4 T \mathrm{~ns}$ & $1,63 \mathrm{~ns}$ & $0,93 \mathrm{~ns}$ & $1,00 \mathrm{~ns}$ & $0,89 \mathrm{~ns}$ & $0,74 \mathrm{~ns}$ \\
\hline CV $(\%)$ & 29.24 & 3.17 & 0,39 & 8,84 & 21,21 & 11,80 & 21,41 & 10,19 & 15,83 & 20,95 & 26.77 & 22,15 \\
\hline
\end{tabular}

ns = năo significativo ao nivel de 0,05.

$\therefore$ = significativo ao nivel de 0,05 .

$\ldots=$ significativo ao nivel de 0,01 .

$\cdots *$ significativo oo nivel de 0,001 . 

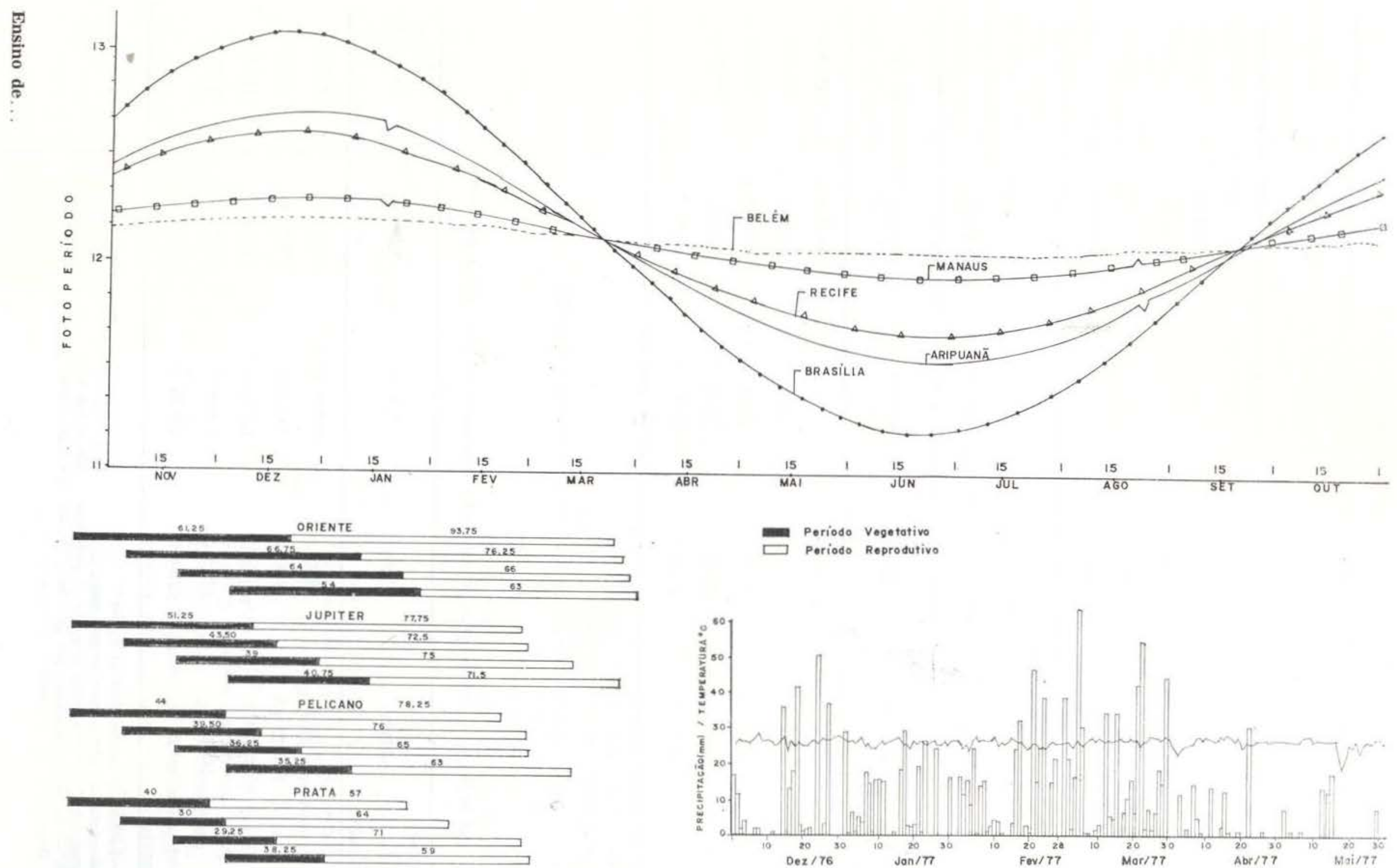

Periodo Vegetativo
$\square$ Periodo Reprodutivo

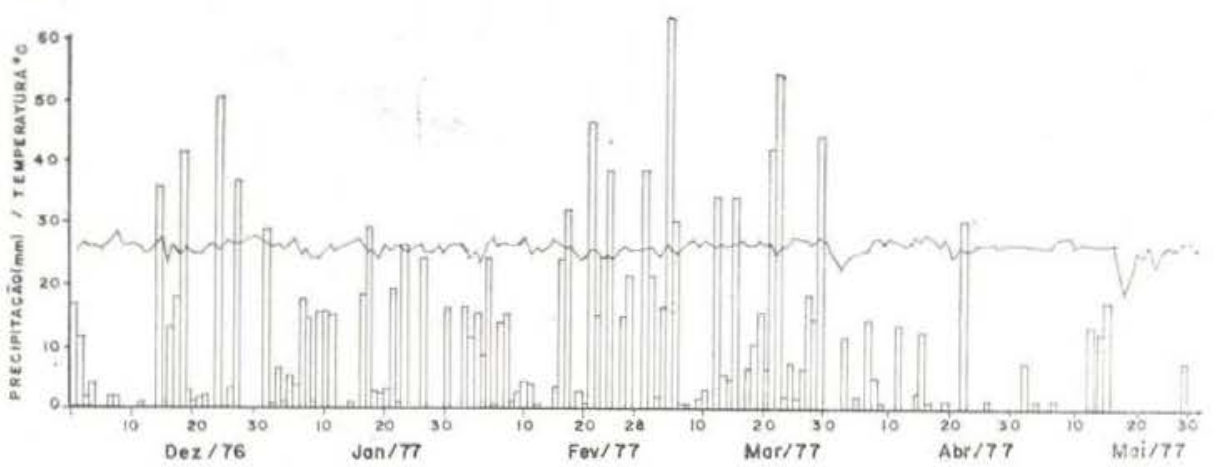

Fig. 1 - Dados sobre o fotoperíodo (Belém, Manaus, Recife, Aripuanā e Brasilia), ciclo da planta (época de plantio), tempcratura e precipitação (dados me. teorológicos de Aripuanā-MT. 1976/77 
QUADRO II - Dados sobre o Stand das plantas

\begin{tabular}{|c|c|c|c|c|c|}
\hline Epocas (E) & Júpiter & Prata & Oriente & Pelicano & $\hat{\mathrm{m}}(E)$ \\
\hline E 1 & 149,50 & 126,25 & 162,75 & 140,50 & 144.75 \\
\hline E 2 & 143,25 & 124,75 & 147,75 & 153,50 & 142,31 \\
\hline E 3 & 134,50 & 148,78 & 151,50 & 128,50 & 140.82 \\
\hline $\begin{array}{l}\mathrm{E} 4 \\
\hat{\mathrm{m}}(\mathrm{V})\end{array}$ & $\begin{array}{l}122,50 \\
137,44\end{array}$ & $\begin{array}{l}141.75 \\
135,38\end{array}$ & $\begin{array}{l}151,25 \\
153,31\end{array}$ & $\begin{array}{r}128,50 \\
137,75\end{array}$ & 136,00 \\
\hline
\end{tabular}

QUADRO III - Dados sobre a Floração, expressos em dias após o plantio.

\begin{tabular}{|c|c|c|c|c|c|}
\hline Épocas (E) & Júpiter & Prata & Oriente & Pelicano & $\hat{m}(E)$ \\
\hline E 1 & $51,25 \mathrm{e}$ & $40,00 \mathrm{~g}$ & $61,25 \mathrm{c}$ & $44,00 \mathrm{f}$ & 49.12 a \\
\hline E2 & $43,50 \mathrm{f}$ & $30,00 i$ & 66,75 a & $39,50 \mathrm{~g}$ & $44,94 \mathrm{~b}$ \\
\hline E3 & $39,00 \mathrm{~g}$ & 29,25 & $64,00 \mathrm{~b}$ & $36,25 \mathrm{~h}$ & $42,12 \mathrm{c}$ \\
\hline $\begin{array}{l}\mathrm{E} 4 \\
\hat{\mathrm{m}}(\mathrm{V})\end{array}$ & $\begin{array}{l}40,75 \mathrm{~g} \\
43,62 \mathrm{~B}\end{array}$ & $\begin{array}{l}28,25 \quad i \\
31,88 \quad D\end{array}$ & $\begin{array}{l}54,00 \mathrm{~d} \\
61,50 \mathrm{~A}\end{array}$ & $\begin{array}{l}35,25 \mathrm{~h} \\
38,75 \mathrm{C}\end{array}$ & $39,56 \mathrm{~d}$ \\
\hline
\end{tabular}

ABC - Comparoçāo de médios entre as variedades.

abc - Comparação de médias entre as épocas.

abed... - Comparaçẩo de médias entre interação $X$ variedades.

Teste de Tukey - As médias separadas por uma letra diferem significativamente $(P<0,05)$.

QUADRO IV - Dados sobre a maturação, expressos em dias após a germinação.

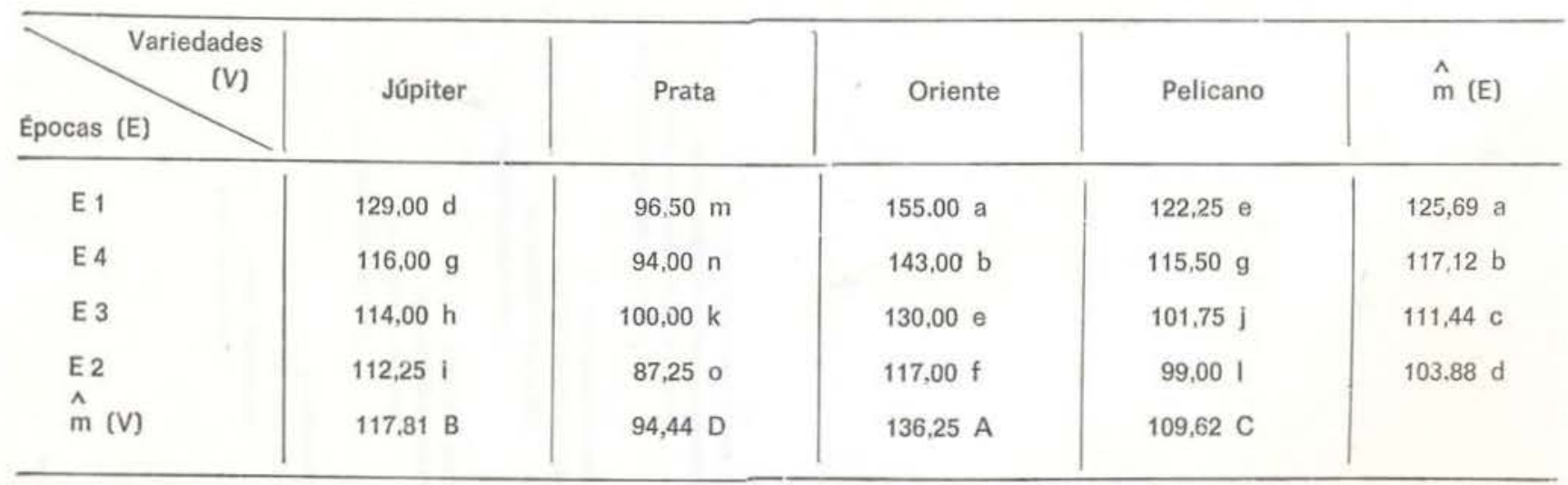

abe - Comparaçâo de médias entre as épocas.

ABC - Comparaçāo de médias entre as varicdades.

abed... - Comparaçāo de médias entre interaçāo $X$ variedades.

Teste de Tukey - As médias separadas por uma letra diferem significativamente $(P<0,05)$. 
ríodo vegetativo, sendo isto mais notado em variedades mais tardias. Quando há atraso no plantio a partir da data de início de maio, há uma redução de período vegetativo, também mais acentuada em variedades tardias, porém, quando plantada em agosto, todas as variedades floresceram ao mesmo tempo, independentemente do seu grau de maturação.

Os primórdios florais são formados quando as plantas são submetidas a fotoperíodos de 8 a 10 horas; quando há um aumento de fotoperíodo, as variedades precoces diferem das tardias por apresentarem iniciação floral e frutificação, ocorrendo em períodos maiores, sendo que as tardias crescem vegetativamenie quando submetidas a fotoperíodo que excedem 15 horas (Borthwick \& Parker, 1939).

O fotoperíodo parece ser a variável principal associada com a influência da data do plantio sobre a maturação, porém outras, como a temperatura e umidade, podem apresentar

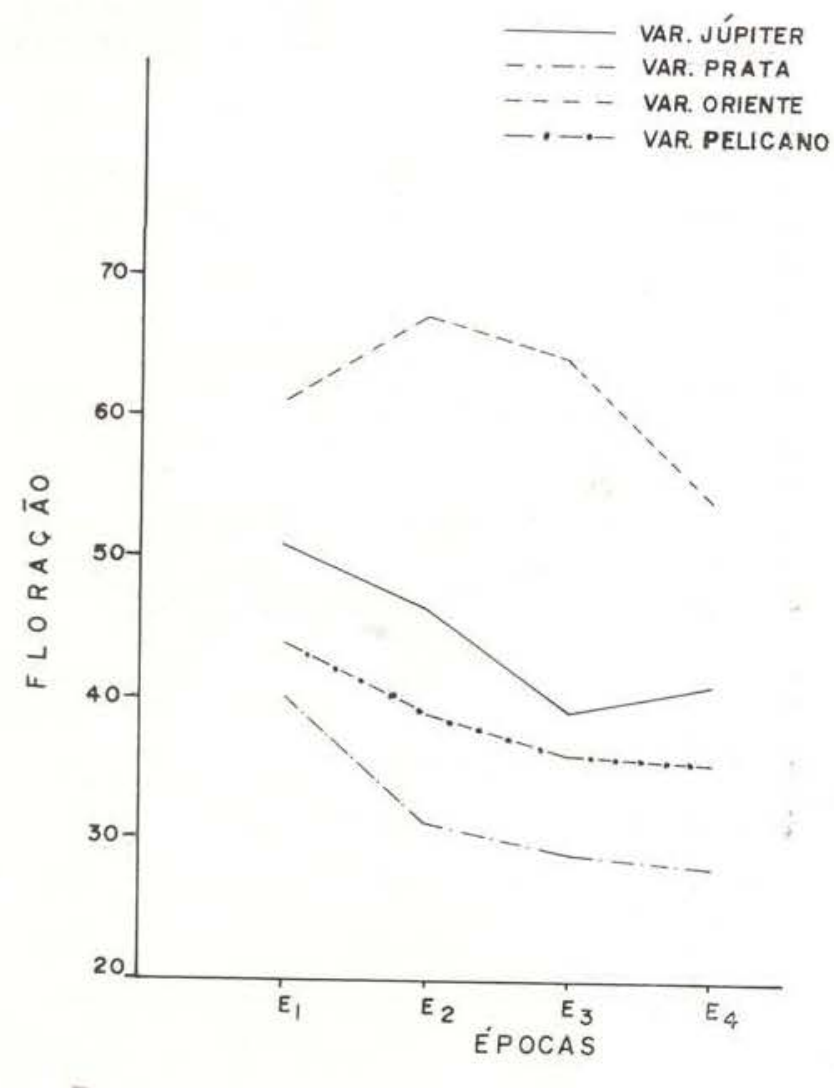

Fig. 2 - Dados da floração, expressos em dias uapós a germinação, obtidos no ensaio em épocas de plantio em Aripuanã - MT. 1976/77

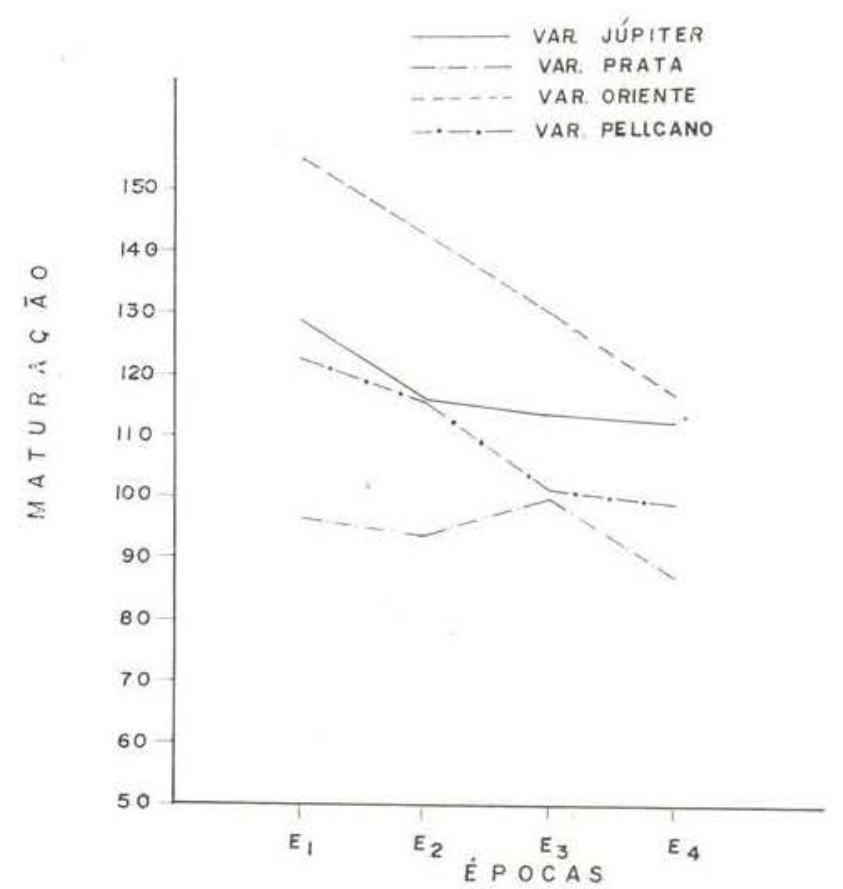

Fig. 3-Dados sobre a maturação expressos em dias após a germinação, obtidos no ensaio em épocas de plantio em Aripuană - MT. 1976/77

efeitos importantes (Camper \& Smith, 1958; Hartwig, 1954). O atraso na data de plantio, traz um atraso maior na maturação de variedades precoces do que nas tardias (Feaster, 1949; Hartwig, 1954; Osler \& Carter, 1954; Weiss et al., 1950), entretanto Torrie \& Briggs (1955) descobriram que os dois tipos de variedades apresentavam um retardamento igual na maturação com um atraso no plantio, existindo uma relação de um dia de atraso na maturação para cada dois de atraso no plantio

No Brasil, principalmente na região Centro-Sul, trabalhos feitos por Miyasaka (1965) consideram que a soja, sendo de dias curtos, floresce quando os dias começam a tornar-se mais curtos ou seja em fevereiro. Sediyama et al. (1971) e Atthow \& Swea (1968) indicam que a soja não apresenta maturação satisfatória nos plantios anteriores a 25 de outubro e posteriores a 10 de dezembro.

Verificando os resultados, houve uma gradativa precocidade com o atraso de plantio em modo geral, tanto na floração como na maturação. Em todas variedades, houve redução nos períodos vegetativo e reprodutivo para as variedades Oriente e Pelicano, conforme o 


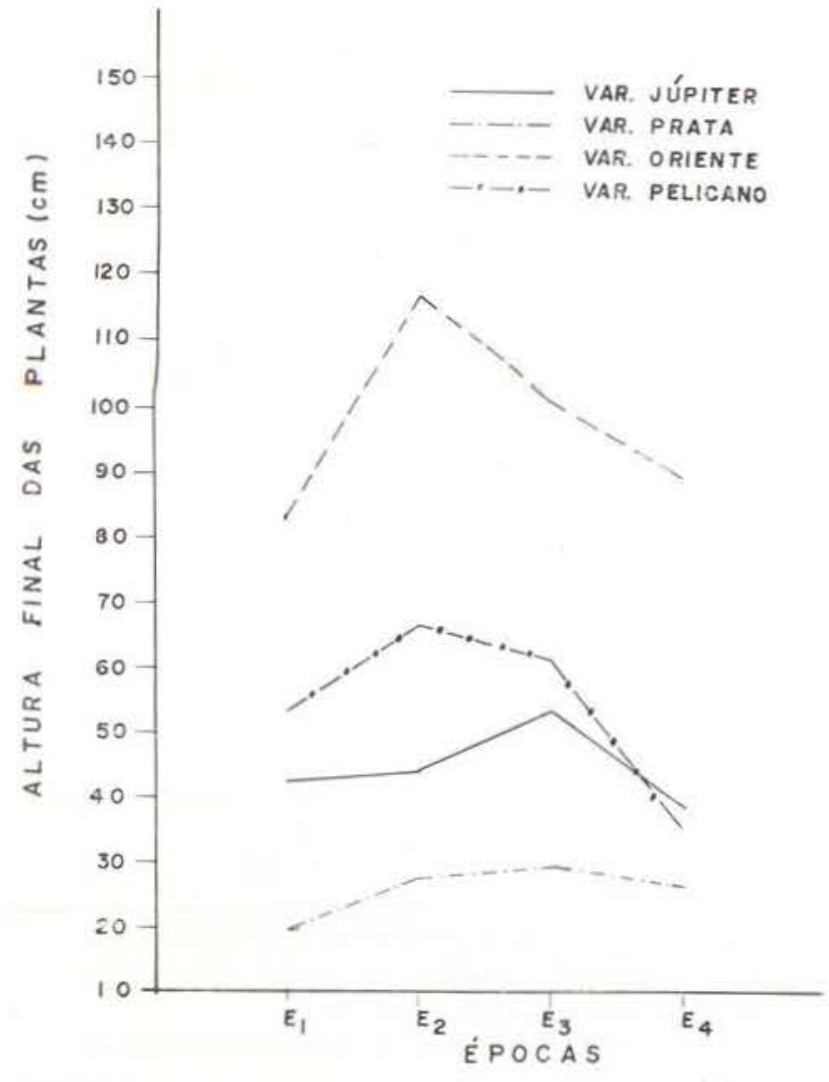

Fig. 4 - Dados sobre a altura final das plantas expressos em centímetros, obtidos no ensaio em épocas de plantio em Aripuanã MT. 1976/77

atraso no plantio. A variedade Prata aumentou o período reprodutivo com o atraso no plantio. atingido pela excessiva precipitação, enquanto que a variedade Júpiter teve uma oscilação de 6,25 dias, no período reprodutivo indiferente à época de plantio.

Notamos que, após uma chuva prolongada, com o fotoperíodo de 12 horas houve uma tentência de as plantas atingirem a maturidade. ou com fotoperiodo de 11:45 hs. com redução da umidade do solo.

A variedade Oriente tem seu caráter de atingir a maturidade com fotoperíodo de 11:45 hs. independentemente da época de plantio.

\section{ALTURA DAS PLANTAS}

Os resultados mostram que esta característica foi atingida pela época de plantio, variedade $e$ interação épocas $x$ variedades de maneira significativa. A altura da planta ge. ralmente diminui com atraso no plantio (Garner \& Allard, 1930; Osler \& Cartter, 1954; Torrie \& Briggs, 1955; Weiss et al., 1950; Abel, 1961). Neste ensaio, também se mostrou que houve redução de maneira geral com atraso de plantio com exceção de $E_{1}$ que, talvez, aqui na região tropical, encaixe bem com a afirmação de Hartwig (1954) de que, em fotoperiodos curtos, associados com plantios bastante precoces, neste caso, florescimento precoce pode resultar numa redução bastante marcada na altura da planta.

A variedade Oriente teve o maior crescimento, seguida de Pelicano, Júpiter e Prata. A Oriente eın $E_{2}$ a aitura foi máxima e foi decrescendo com o atraso de plantio, sendo que em $E_{1}$ plantio muito precoce houve redução na altura; isto ocorreu também na variedade Pelicano. Nas variedades Júpiter e Prata, a altura

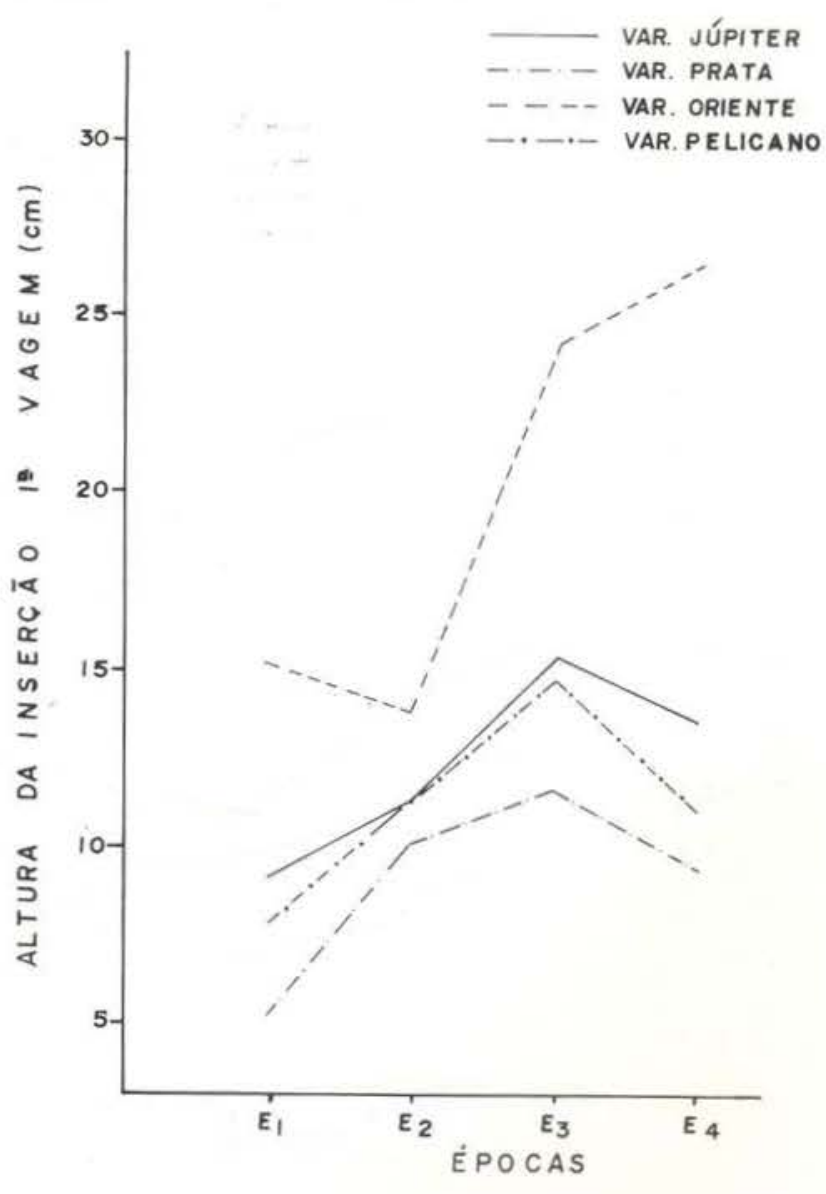

Fig. 5 - Dados da altura da inserção da 1.a vagem, obtidos no ensaio em épocas de plantio em Aripua. nä - MT. 1976/77 
QUADRO V - Dados sobre a altura final das plantas expressos em centímetros.

\begin{tabular}{|c|c|c|c|c|c|}
\hline Epocas (E) & Júpiter & Prata & Oriente & Pelicano & $\hat{\mathrm{m}}(\mathrm{E})$ \\
\hline E 1 & $42,92 \mathrm{f}$ & $19,70 \mathrm{i}$ & $82,50 \mathrm{c}$ & $53,42 \mathrm{e}$ & $49,64 \mathrm{~b}$ \\
\hline E 2 & $44,80 \mathrm{f}$ & 27,55 ghi & $110,62 \mathrm{a}$ & $66,30 \mathrm{~d}$ & 62,32 a \\
\hline E3 & 53,45 e & $29.52 \mathrm{gh}$ & $101,42 \mathrm{~b}$ & $61,32 \mathrm{~d}$ & 61,43 a \\
\hline $\begin{array}{c}E 4 \\
\wedge\end{array}$ & & 26,12 hi & $87.78 \mathrm{c}$ & & $47,75 \mathrm{~b}$ \\
\hline$m(V)$ & $45,58 \mathrm{C}$ & $25,72 \mathrm{D}$ & $95,58 \mathrm{~A}$ & 54,25 B & \\
\hline
\end{tabular}

ABC - Comparação de médias entre os variedades.

abc - Comparação de médias entre as épocas.

abed... - Comparaçāo de médias entre interaçâo $X$ variedades.

Teste de Tukey - As médias separadas por uma letra diferem significativamente $(\mathbb{P}<0,05)$.

QUADRO VI - Dados sobre o diâmetro do caule.

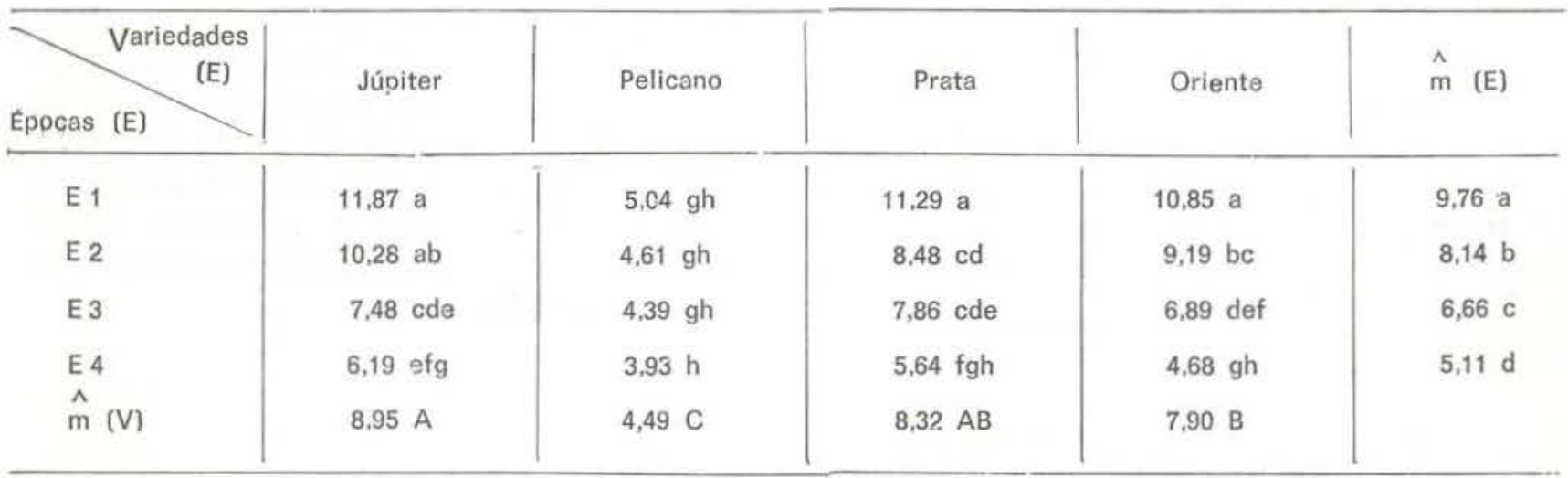

ABC - Comparaçäo e médias entre as variedades.

abc - Comparaçōo de médias entre as épocas.

abcd... - Comparaçāo de médios eritre interaçāo $X$ variedades.

Teste de Tukey - As médias separadas por uma letra diferem significativamente $(P<0,05)$.

QUADRO VII - Dados sobre a altura de inserção da 1" vagem, expressos em centimetros

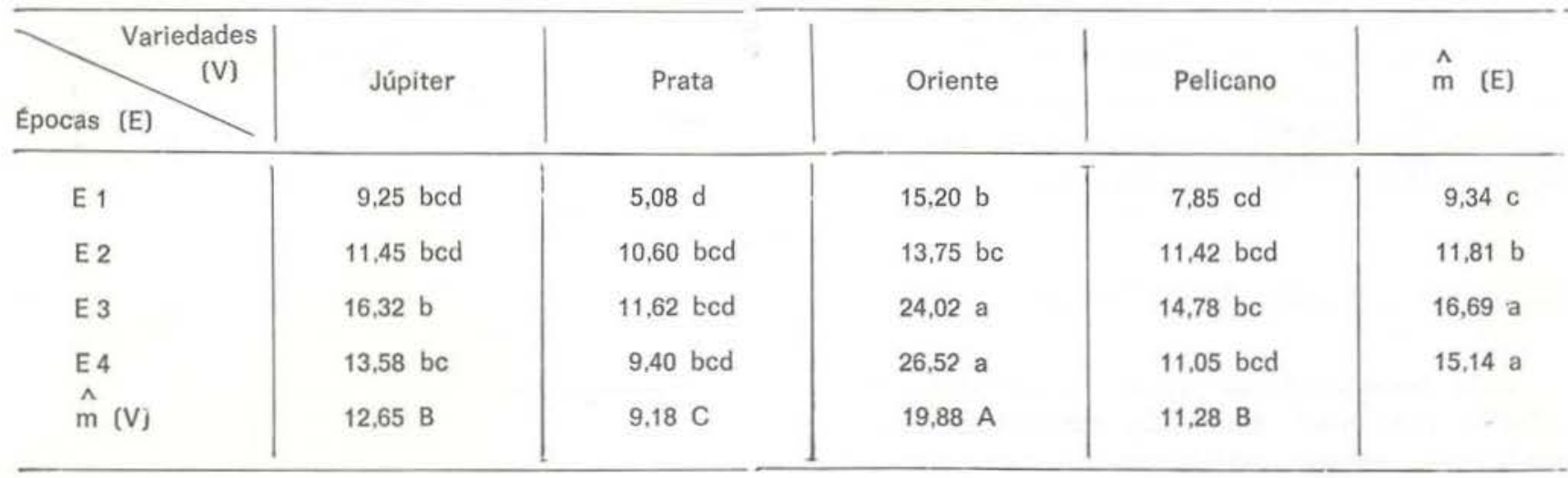

$A B C=$ - Comparaçâo de médias entre as variedades.

abc - Comparação de médias entre as épocas.

abcd... - Comparação de médias entre interação $X$ variedades.

Teste de Tukey - As médias separadas por uma letra diferem significativamente $(P<0,05)$.

Ensino de... 


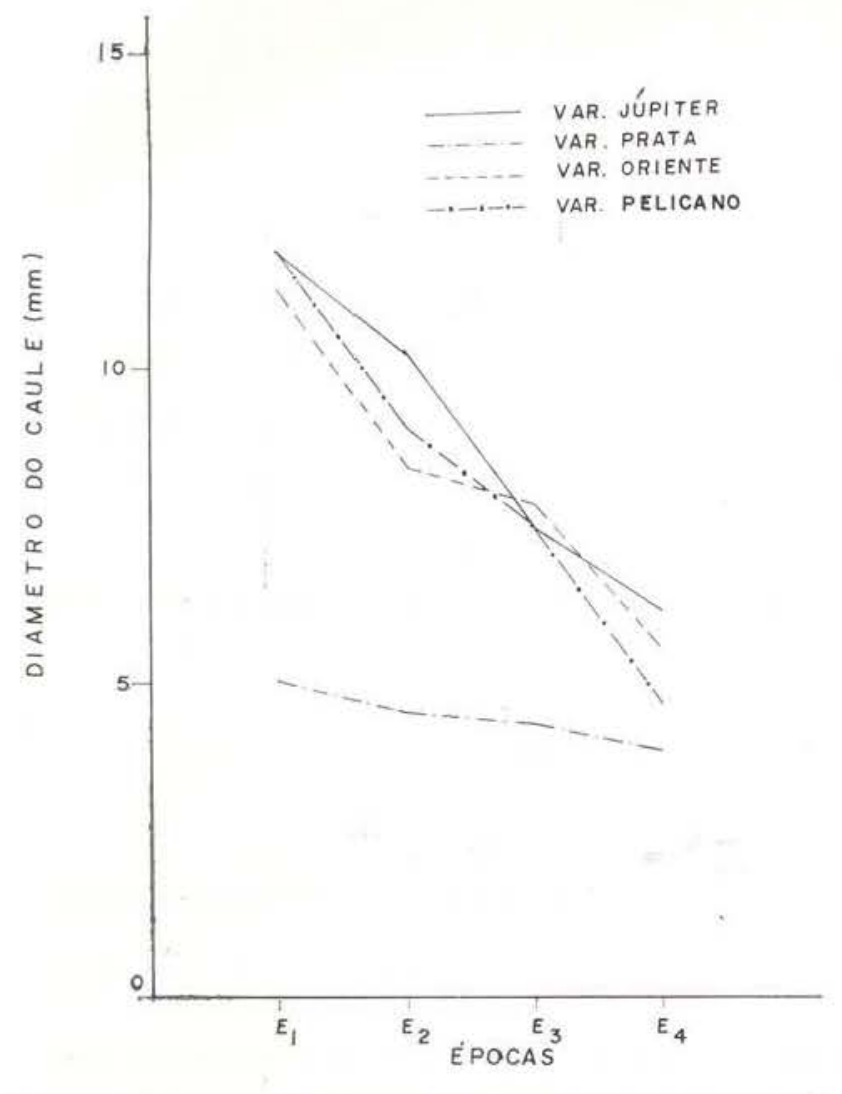

Fig. 6 - Dados sobre o diâmetro do caule expressos em centímetros, obtidos no ensaio em épocas de plantio em Aripuanã - MT. 1976/77

máxima verificou-se na $E_{3}$ e reduzindo, dado o seu plantio precoce e tardio. A altura da planta influi diretamente no controle de ervas daninhas e acamamento das plantas, e está ligada ao ciclo vegetativo da cultura e à disponibilidade de água e energia, isto é, a $E_{2}$ foi a que apresentou a maior altura no presente estudo, e refletiu diretamente na produtividade, correlacionando também com a floração ou com o período vegetativo da planta. Durante o ensaio, podemos notar (Fig. 1) que não houve a falta de umidade no solo.

\section{ALTURA DA INSERÇÃO DA 1 a VAGEM}

Esta característica influi diretamente na colheita mecânica, causando menor ou maior perda no campo, refletindo diretamente na produção. Relos resultados obtidos, verificase que houve influência de épocas, variedades e interação, épocas $x$ variedades, houve ainda o aumento gradativo da altura da inserção da $1^{\text {a }}$ vagem, com o atraso da época de plantio de modo geral, sendo que a altura da inserção da $1^{a}$ vagem maior foi notada em $E_{3}$. A variedade Oriente tem a maior altura da inserção da $1^{\text {a }}$ vagem com $19,87 \mathrm{~cm}$; seguem-se a Júpiter com 12,65 cm. Pelicano com 11,28 cm e Prata com $9,18 \mathrm{~cm}$. A altura mínima do corte com colheita mecânica é em torno de $10 \mathrm{~cm}$ do solo, sendo o terreno plano e contando com bom operador, com algumas adaptações sob a plataforma da colhedeira, pode-se diminuir até $7 \mathrm{~cm}$ a altura do corte. Então com exceção da variedade Prata de $E_{1}$, pode fazer-se colheita mecânica sem a perda de grãos no campo.

\section{DIÂMETRO DO CAULE}

Esta característica também foi atingida pela época, variedade e interação épocas $x$ variedades e pode verificar-se que está correlacionada com o ciclo vegetativo da cultura: quanto maior o período de desenvolvimento, maior o diâmetro e quanto menor o período de desenvolvimento menor o diâmetro. Houve portanto redução de diâmetro com $\sigma$ atraso da época de plantio.

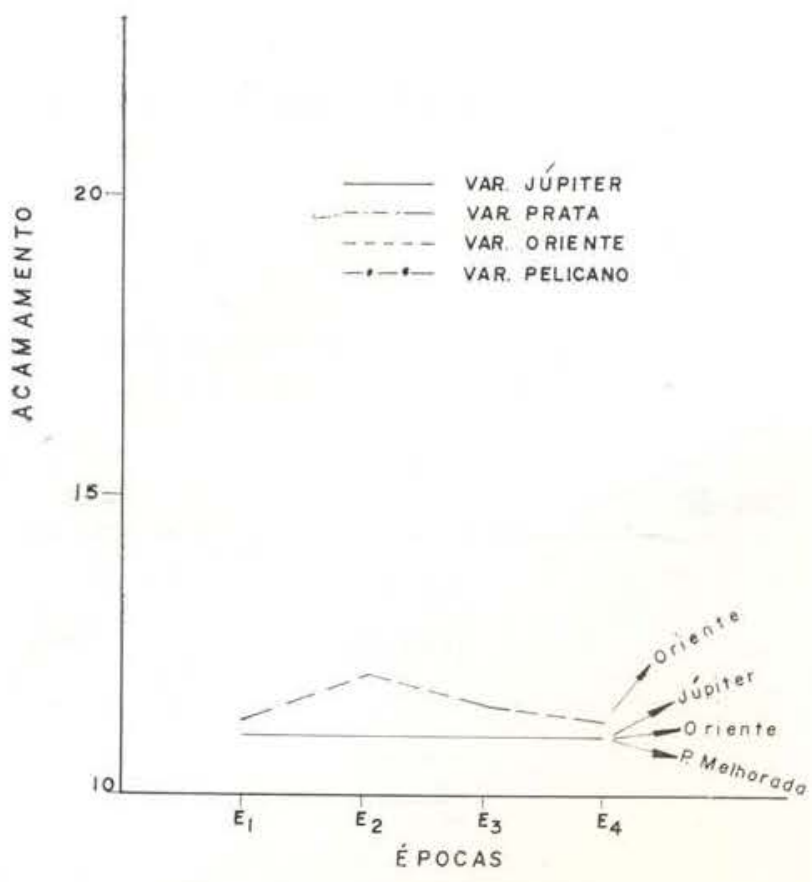

Fig. 7 - Dados sobre o acamamento obtidos no ensaio em épocas de plantio em Aripuanä-MT. 1976/77 
QUADRO VIII - Dados sobre o número de vagens por planta.

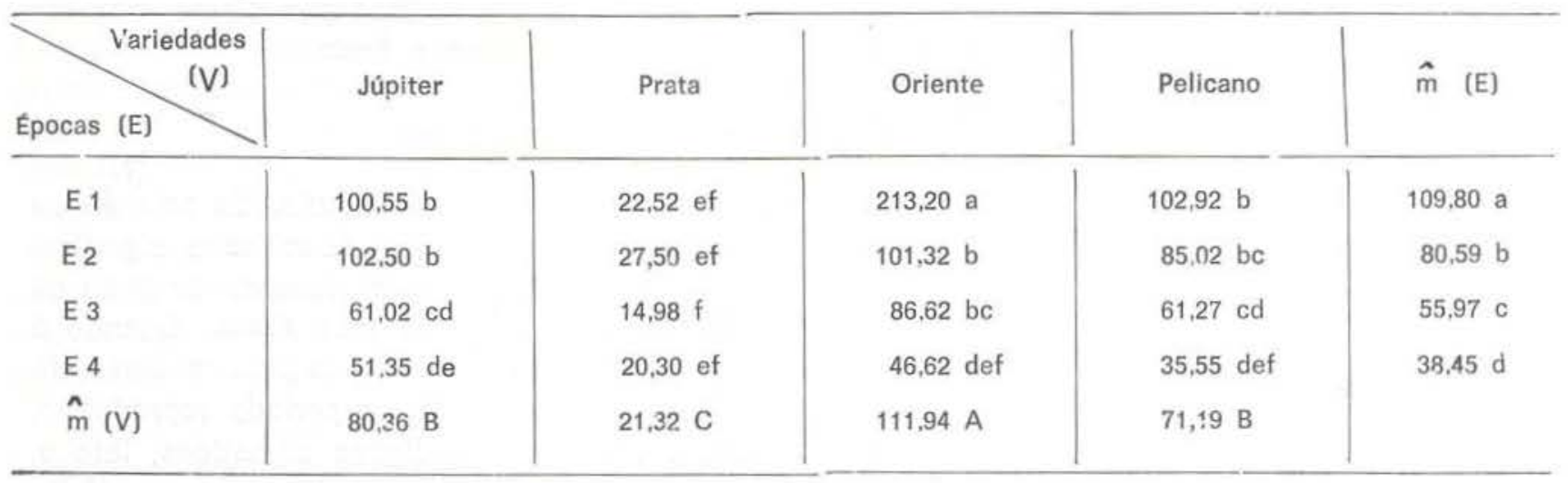

ABC - Comparaçāo de médias entre as variedades.

abc - Comparaçẩo de médias entre as épocas.

abed... - Comparação de médias entre interaçăo $X$ voriedades.

Teste de Tukey - As médios separadas por uma letra diferem significativamente $(P<0,05)$.

Esta característica influi diretamente nas colhedeiras mecânicas: quanto maior o diâmetro, maior desgaste da maquinaria, requerendo maior energia no trabalho.

\section{ACAMAMENTO}

Esta característica pode influir diretamente na produtividade. Em períodos de maior precipitação as plantas acamadas, por falta de ventilação, começam a apodrecer, dado o ataque de fungos causadores de podridão. $\mathrm{O}$ acamamento aumenta quando há um atraso na época de plantio, havendo uma grande variabilidade nas variedades com relação ao acatamento (Osler \& Carter, 1954); entretanto diminui com o atraso no plantio (Abel, 1961); porém Torrie \& Briggs (1955) não encontraram efeitos de épocas de plantio sobre o acamamento. No presente ensaio, não houve efeito significativo entre épocas de plantio; houve efeito significativo entre as variedades $e$ interação variedades $x$ épocas, isto é, somente a variedade Oriente se acamou e mostrou que é ligada diretamente à altura das plantas; no plantio feito no $E_{2}$, houve maior grau de aca-

QUADRO IX - Dados sobre o Acamamento, dados expres sos em: 1-1,9 - plantas sem acamamento; 2-2,9 - plantas encurvadas; $3,0-3,9$ - plantas com 25 a $30 \%$ acamamento; $4-4,9$ - plantas com $50-75 \%$ acamadas e $5-+$ de $75 \%$ acamadas.

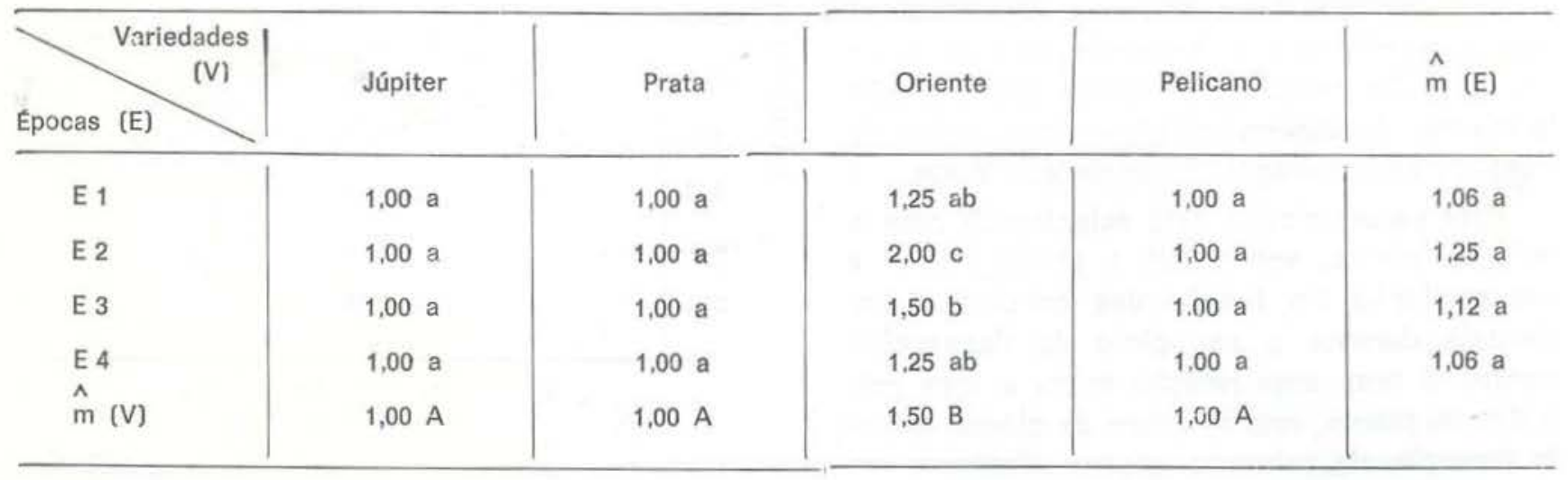

$A B C=$ - Comparação de médias entre as variedaces.

abc - Comparaçăo de médios entre as épocas.

abcd... - Comparaçâo de médios entre interação $X$ variedades.

Teste de Tukey - As médias separadas por uma letra diferem significativamente $(P<0,05)$.

Ensino de.. 


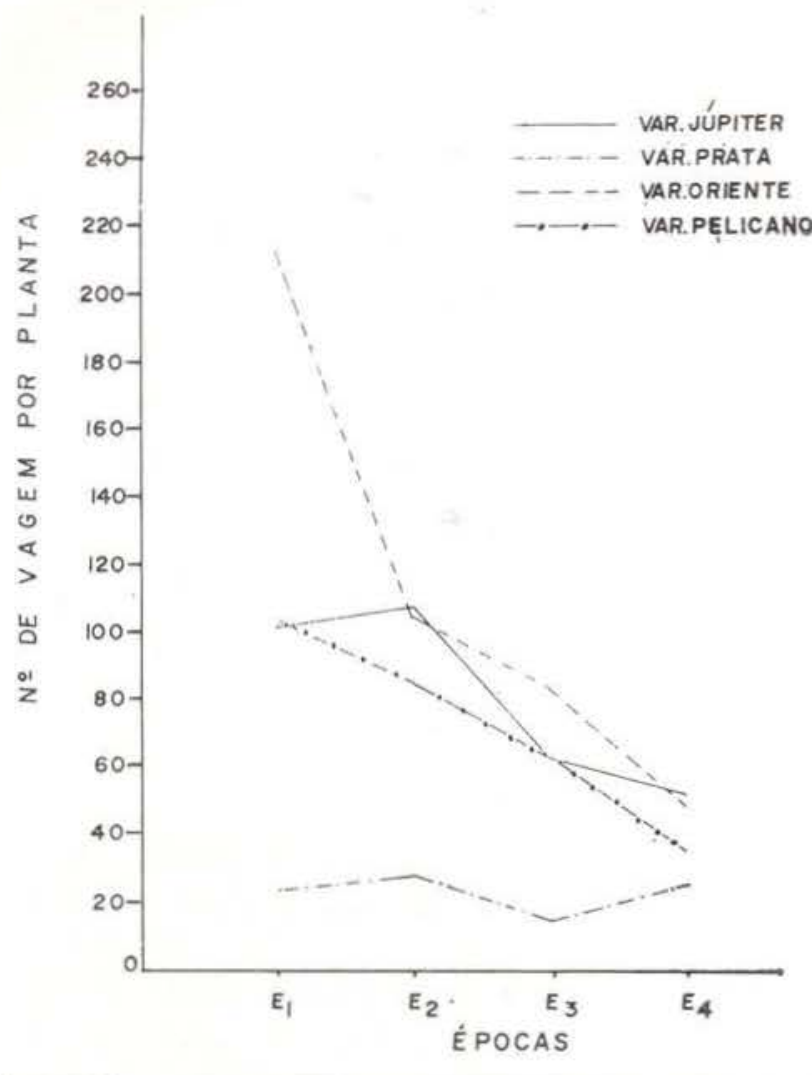

Fig. 8 - Dados do N.o de vagens por planta, obtidos no ensaio em épocas de plantio em Aripuanã MT. 1976/77

mamento seguido de $E_{3}, E_{1}$ e $E_{4}$, mas isto năo comprometeu a produtividade, porque não houve contato direto com o solo e nem apodrecimento das vagens, isto é, as plantas se curvaram mas houve ventilação suficiente para evitar o apodrecimento.

\section{NÚMERO DE VAGENS POR PLANTA}

Esta característica sofreu a influência de épocas, variedades e interação épocas $x$ va riedades. De modo geral, houve uma redução de número de vagens por planta com atraso de plantios, com exceção da variedade Prata.

Esta característica está relacionada com o ciclo da planta, sendo que a planta regula a sua produção em função das condições ambientais durante o seu ciclo de desenvolvi. mento. E tem uma relação entre a área produtiva da planta, isto é, altura da planta, altura da inserçẫo da primeira vagem, distância entre o nó da planta, número de galhos existentes e número de nó por planta. Está bem relacionada, neste caso, à altura da planta e ao número de vagens; a variedade Oriente teve maior número de vagens por planta, seguida de Júpiter, Pelicano e Prata.

\section{PESO DE 100 SEMENTES}

Esta característica foi atingida pela época de plantio e variedades, de maneira significativa. A variedade Júpiter teve maior peso de 100 sementes seguida pela Prata. Quando à época de plantio, foi atingido pela condição climática, porque na $E_{4}$, no período reprodutivo, houve melhores condições climáticas, isto é, já com poucas chuvas, mas não secas (falta de umidade) para prejudicar as plantas e maturação dos grãos.

\section{PRODUÇÃO DE GRÃOS}

Esta característica é considerada como a mais importante, já que é uma conseqüência das contribuições genéticas da planta dentro de um determinado conjunto de condiçōes am.

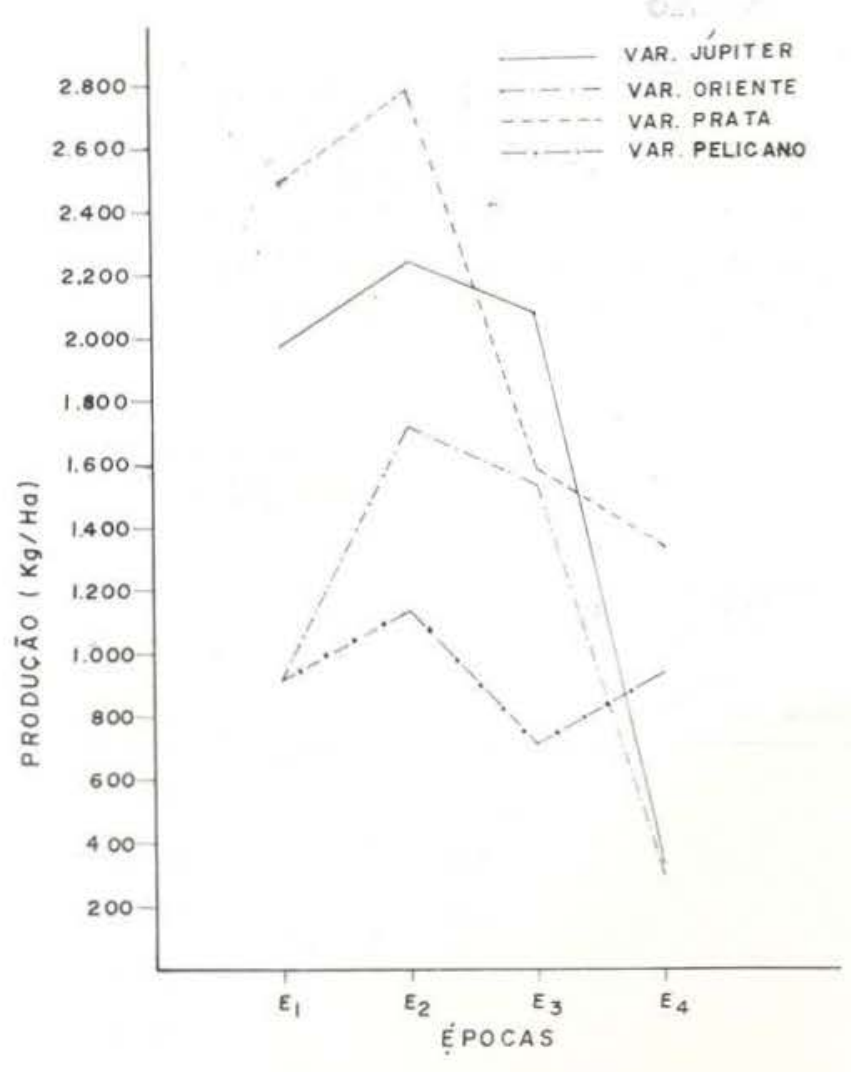

Fig. 9 - Dados sobre a produção de grãos expressos em $\mathrm{kg} / \mathrm{ha}$, obtidos no ensaio em épocas de plantio em Aripuanã - MT, 1976/77 
bientais. Houve uma influência das épocas, variedades $e$ interaçăo épocas $x$ variedades. A variedade Oriente produziu mais, seguida de Júpiter, Pelicano e Prata. A produtividade depende do ciclo da planta, isto é, início do desenvolvimento até a maturação, sendo que este fator influi diretamente na zona de produção (composta de: altura da planta, diấmetro do caule, altura da inserção da $1^{\text {a }}$ vagem, número de vagens por planta, número de nó por planta e número de grãos por vagem).

Em geral, houve relação direta da altura e número de vagens por planta na produção de grãos. A variedade Oriente mostrou altura e número de vagens maiores do que as outras; assim a sua produção foi maior, enquanto a variedade Prata que teve menor altura e menor número de vagens, apresentou produção baixa. Agora na variedade Júpiter a produção foi superior à da Pelicano, apesar de sua altura baixa, mas o númerc de vagens por planta e peso de 100 sementes foi superior a do Pelicano.

\section{QUALIDADE DA SEMENTE}

Outro fator importante atingido pela data de plantio é a qualidade de sementes, o que condiciona diretamente o valor do produto no mercado e também a viabilidade da semente para o próximo plantio. Altas temperaturas e alta umidade duranie o desenvolvimento da semente causam, freqüentemente, perda de qualidade e o proliferamento de microorganismos nelas. Chuvas, durante a maturação, são detrimentos para a qualidade e chegam até a causar germinação de sementes dentro de vagens, por outro lado, temperaturas bem altas

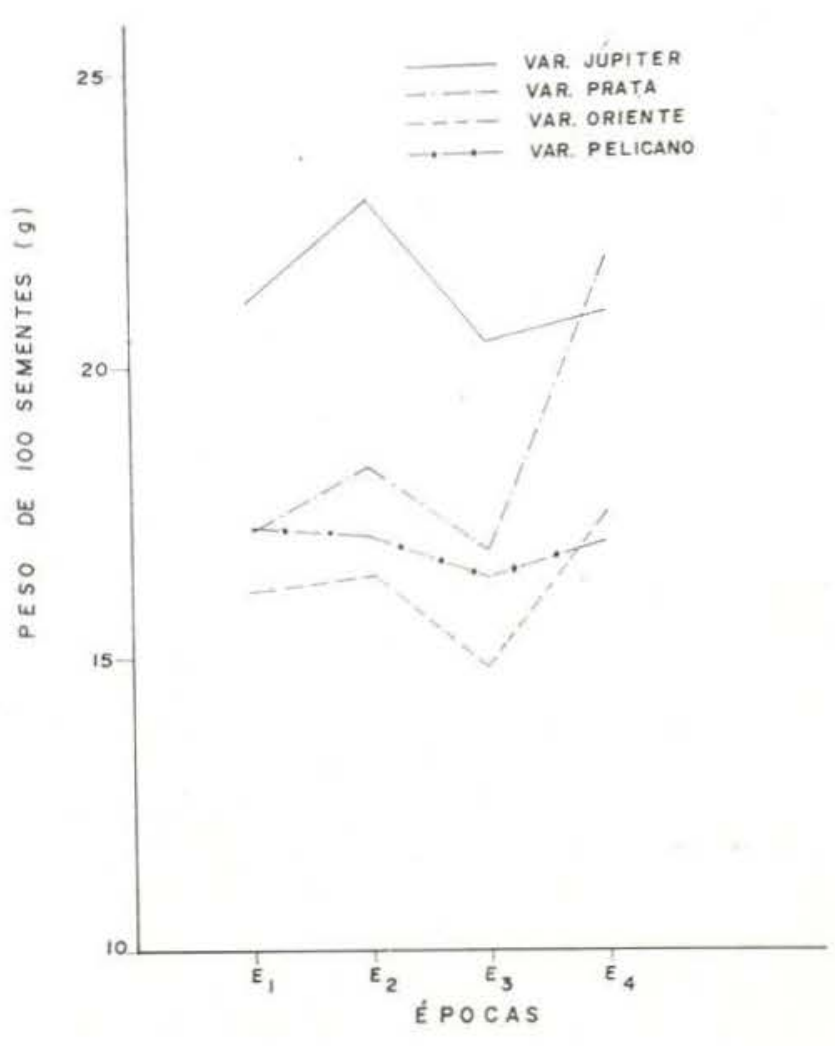

Fig. 10 - Dados sobre peso de 100 sementes expressos em gramas, obtidos no ensaio em épocas de plantio em Aripuanã-MT. 1976/77. ,

QUADRO X - Dados sobre o peso de 100 sementes, expressos em gramas.

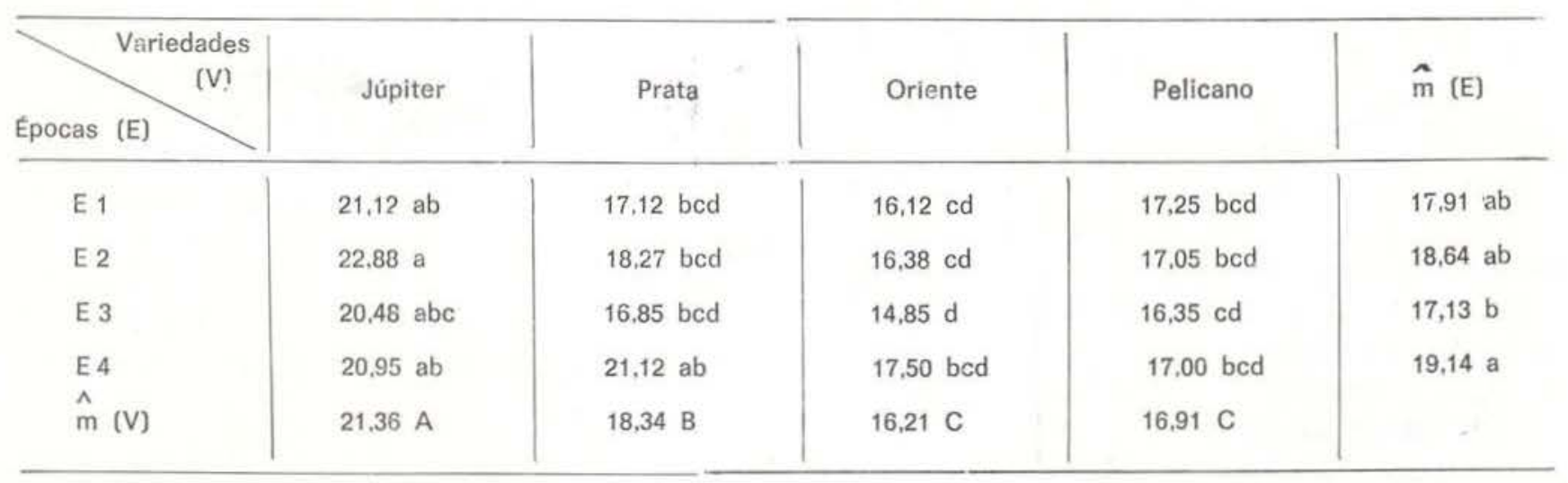

ABC" - Comparaçẫo de médias entre os variedades,

abc - Comparaçăo de médias entre as épocas.

abcd... - Comparação de médias entre interação $X$ variedades.

Teste de Tukey - As médias separadas por uma letra diferem significativamente $(P<0,05)$.

Ensino de... 
QUADRO XI - Dados sobre ã produção de grãos, expressos em $\mathrm{kg} / \mathrm{ha}$.

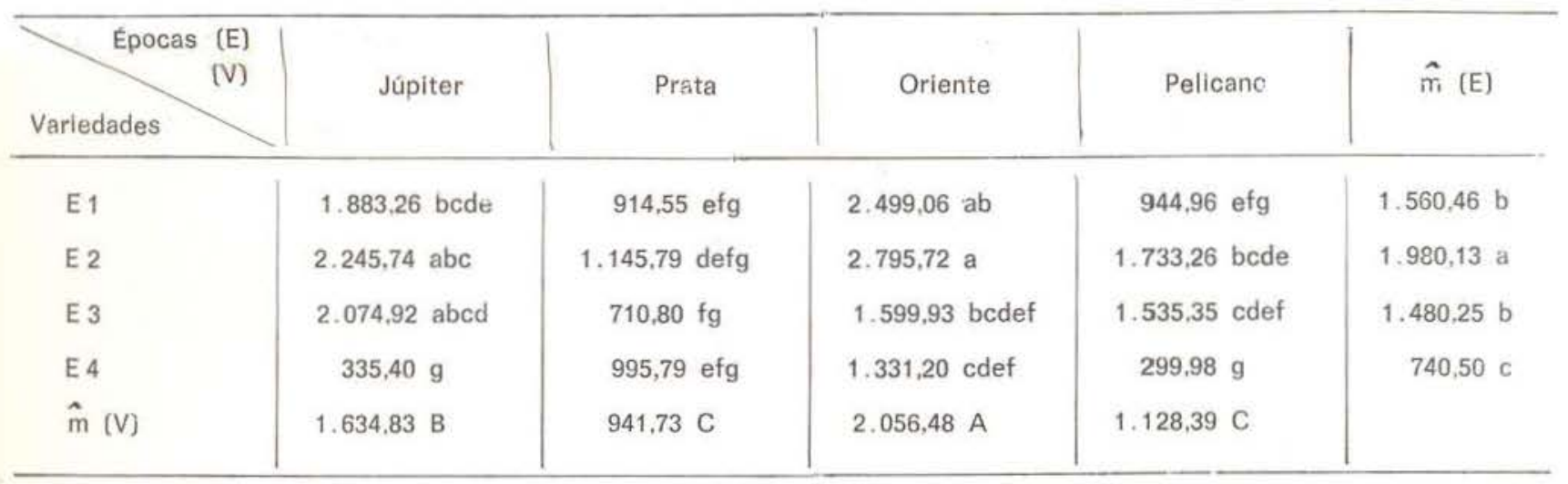

ABC - Comparaçấo de médias entre as variedades.

ab - Comparaçấo de médias entre as épocas.

abdcefg - Comparaçōo de médias entre interaçâo época $X$ variedades.

Teste de Tukey - As médias separadas por uma letra diferem significativamente (P 0,05$)$.

sob as condiçōes de secas podem parar a maturaçâo das sementes, ocasionando a presença de sementes verdes e enrugadas (Yuyama, 1976). Sumarizando, de um modo específico, a qualidade da semente depende das condições ambientais: se estas forem secas e frias fornecem uma boa qualidade de sementes; condições quentes e úmidas, com chuvas freqüentes produzem má qualidade; tempo seco com temperatura alta ou mesmo com geadas produzem sementes pequenas com coloração acinzentada.

De um modo geral, um atraso na época de plantio traz como conseqüência uma dimi- nuição no conteúdo de óleo (Feaster, 1949; Osler \& Cartter, 1954; Weiss et al., 1950; Torrie \& Briggs, 1955; Viljoen, 1937) e um aumento em proteina (Osler \& Cartter, 1954; Viljoen. 1937) e no índicce de iodo (Feaster, 1949; Osler \& Cartter, 1954; Weiss et al., 1950). Porém, Weiss et al. (1950) assim como Torrie \& Briggs (1955) não encontraram variação em proteína pelas épocas de plantio. $O$ índice de iodo é influenciado inversamente pela temperatura existente na síntese de óleo das sementes (Osler \& Cartter, 1954), de um modo geral, há um aumento no índice de iodo com um atraso no plantio (Torrie \& Briggs, 1955).

QUADRO XIi - Dados sobre as Sementes Estragadas, expressos em porcentagem.

\begin{tabular}{|c|c|c|c|c|c|}
\hline Epocas (E) & Júpiter & Prata & Oriente & Pelicano & $\hat{m}(E)$ \\
\hline E 1 & $22,64 a b$ & $12,23 \mathrm{a}$ & $19,18 \mathrm{ab}$ & $22,81 \mathrm{ab}$ & 19,21 a \\
\hline E 2 & $22,37 \mathrm{ab}$ & $23,73 \mathrm{ab}$ & 25,82 b & $27,46 \mathrm{~b}$ & $24,84 \mathrm{~b}$ \\
\hline E3 & $16,35 \mathrm{ab}$ & $39,36 \mathrm{c}$ & $24,51 \mathrm{ab}$ & $19,64 \mathrm{ab}$ & $24,97 \mathrm{~b}$ \\
\hline E 4 & $20,95 a b$ & $23,57 \mathrm{ab}$ & $23,63 \mathrm{ab}$ & $22,49 a b$ & $22.66 \mathrm{ab}$ \\
\hline$\hat{m}(V)$ & $20.58 \mathrm{~A}$ & $24,72 \mathrm{~A}$ & $23,28 \mathrm{~A}$ & $23.10 \mathrm{~A}$ & \\
\hline
\end{tabular}

ABC - Comporação de médias entre as variedades

abc - Comparaçăo de médias entre as épocas.

abed... - Comparaçāo de médias entre interaçấo $X$ variedades,

Teste de Tukey - As médias separadas por uma letro diferem significativamente $(P<0,05)$. 
QUADRO XIII - Dados sobre a Mancha Púrpura, expressos em porcentagem.

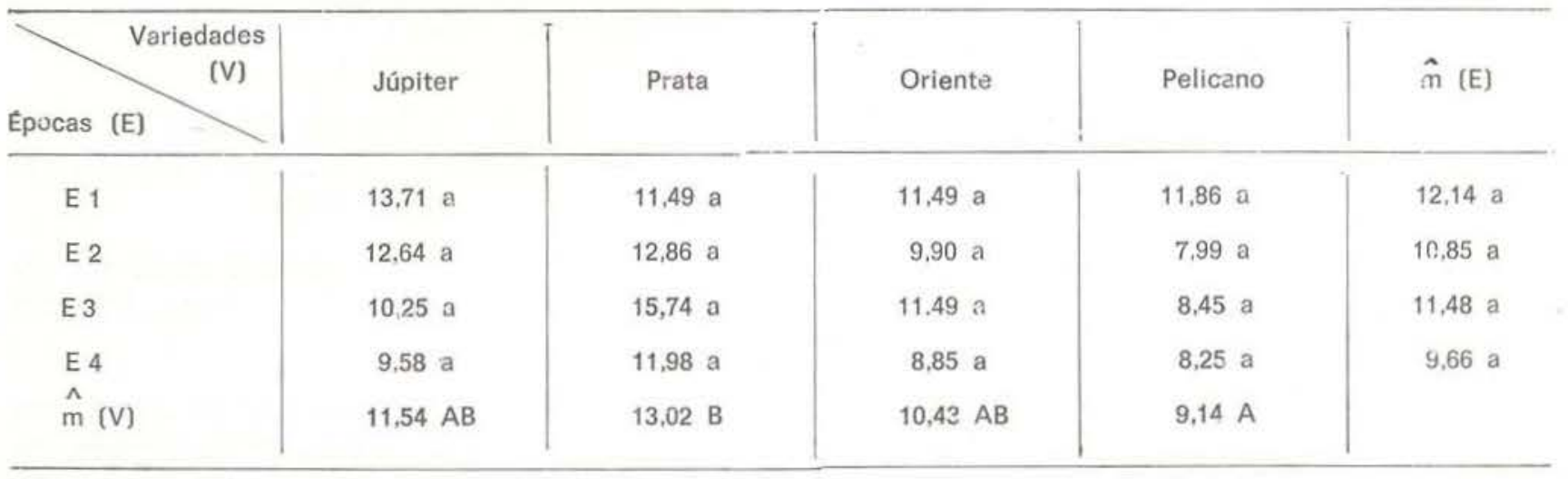

abc - Comparação de médias entre as épocas.

$A B C$ - Comparaçấo de médias entre as variedades.

abcd... - Comparação de médias entre interação $X$ variedades.

Teste de Tukey - As médias separadas por uma letra diferem significativamente $(P<0,05)$.

As épocas de semeadura influenciaram também nus teores de óleo e proteínas; maior teor de proteína no plantio de 30.10 e 25.11 e menor teor de proteína no plantio de 20 de dezembro e o teor de óleo aumentou com retardamento de plantio. E houve decréscimo da altura com o retardamento de plantio (Souza, 1973) .

\section{SEMENTES ESTRAGADAS}

Esta desvantagem foi causada pela época $e$ interação épocas $x$ variedades. Houve menor porcentagem de sementes estragadas no plantio precoce e este foi visivelmente notado na variedade Prata que diferiu significativamente com atraso de plantio, mas não conseguimos notar nas outras variedades, sendo que não houve diferença significativa entre as variedades.

E a variedade Prata foi prejudicada pela excessiva precipitação no período reprodutivo. foi aumentando com atraso de plantio, sendo que houve a redução no período reprodutivo de $E_{1}$ para $E_{4}$, mas pode notar-se no último que já atingiu a maturidade no período seco, isto é, verificando a figura respectiva, a partir de março, nota-se que a precipitação é reduzida.

\section{MANCHA PÚRPURA (Cercospora Kikuchii)}

Esta característica foi sofrida somente pelas variedades, sendo que a variedade Prata é mais suscetível à mancha púrpura; isto pode ser influência da altura da planta, sendo que na variedade de pequeno porte os respingos da chuva aumentam a disseminação da doença na planta e também o período de maturação foi na época de maior precipitação.

\section{DISCUSSŌES GERAIS}

No presente ensaio, abrangendo quatro épocas de plantio e quatro variedades na cultura de soja no Aripuanã, obteve-se um "stand" final das plantas uniforme para todas as parcelas, mostrando que não existiu influência do "stand" nas outras características estudadas. havendo conseqüentemente uma competição igual de plantas em todas as parcelas.

Com relação à floração e à maturaçăo, houve uma precocidade gradativa com o atraso do plantio. Quando o fotoperíodo começou a reduzir e passou para 12:40 h ou menos iniciou a floração, sendo que as parcelas plantadas inicialmente tiveram um periodo vegetativo maior e um ciclo maior, enquanto as parcelas semeadas mais tarde apresentaram ciclo vegetativo e reprodutivo face ao atraso no plantio, com exceção da variedade Júpiter e Prata. Na variedade Júpiter, não houve uma oscilação muito grande; apenas de 6,25 dias no período reprodutivo, indiferentemente à época de plantio. A variedade Prata, dada a excessiva precipitação durante o ciclo reprodutivo, teve um aumento com atraso de plantio, no ciclo reprodutivo e diminuiu no $E_{4}$ que entrou no período seco. 
A produção de grãos maiores foi obtida, em plantio feito em 18 de dezembro, sendo isto uma conseqüência do ciclo da planta que influenciou na zona de produção respectiva, a qual é limitada pela altura da planta, altura da inserção da $1^{\mathrm{a}}$ vagem; aumentou com atraso no plantio. O número de vagens por planta é regulada fisiologicamente durante a época de floração e início de formaçăo de vagens, sendo isto feito por meio de aborto fisiológico, porém as condiçōes durante a floração da parcela semeada, em 18 de dezembro, é melhor acarretando conseqüentemente melhor produção, sendo que cada variedade difere fisiologicamente de outra. O peso de 100 sementes variou para cada variedade, sendo isto conseqüência do gen que originou esta variedade, em geral, houve uma pequena diferença, no peso de 100 sementes, semeadas no $E_{3}$ e $E_{4}$, sendo isto em conseqüência da precipitação durante o seu ciclo reprodutivo; por isso, pode notar-se que, na interação época $x$ variedades, não houve diferenças significativas.

Com relação à qualidade da semente, sendo prejudicada pela presença de mancha púrpura e outros fungos, a variedade Prata é mais suscetível à mancha púrpura, por ter caracteristica de porte baixo e, durante o seu ciclo reprodutivo, até atingir a maturidade, tem uma precipitação excessiva, facilitando a disseminação de fungos.

No presente ensaio, o acamamento não chegou a ser uma característica prejudicial à produção de grãos.

A melhor época de plantio foi a época $E_{2}$ $(18.12 .76)$ que se condicionou às seguintes características :

a) o ciclo da planta é relativamente longo, portanto a zona de produção também é maior;

b) o número de vagens por planta é satisfatório $(\mathrm{m}=80,59)$;

c) produção de grãos como sua conseqüência foi maior com 1980,13 kg/ha. Relacionando esta época com as variedades testadas, as características apresentadas são:

a) a variedade Oriente possui a zona de pro. dução superior à das demais variedades, portanto seu ciclo de vida também maior. Seguida de Júpiter, Pelicano e por fim a Prata;

b) o número de vagens por planta é maior na variedade Oriente. Seguida de Júpiter, Pelicano e finalmente Prata;

c) o peso de 100 sementes foi maior na variedade Júpiter, seguida de Prata, Pelicano e Oriente:

d) a variedade Oriente superou as demais na zona de produção e número de vagens, invariavelmente de seu menor peso de 100 sementes a sua produção de grãos foi maior com 2795,72 kg/ha;

e) a variedade Júpiter superou a variedade Pelicano na produção de grãos, pelo peso de 100 sementes e número de vagens por planta apesar de possuir menor altura, com produção de $2.245,74 \mathrm{~kg} / \mathrm{ha}$;

f) a variedade Pelicano produziu 1733,26 $\mathrm{kg} / \mathrm{ha}$;

g) a variedade Prata, com sua zona de produção menor e número de vagens menor. produziu $1.145,79 \mathrm{~kg} / \mathrm{ha}$.

\section{CONCLUSÃo}

Pela observação dos resultados de discussōes obtidas, podem tirar-se as seguintes conclusões :

a) a floração e maturação foram influenciadas pelas épocas de plantio havendo uma redução no ciclo da planta, seja no período vegetativo seja no período reprodutivo (com exceção das variedades Júpiter $e$ Prata), como uma conseqüência do fotoperíodo e precipitação. As variedades estudadas comportam-se de um modo geral, como o indicado na literatura para variedades tardias (com exceção da variedade Prata que se comportou como variedade precoce);

b) altura da planta, diâmetro do caule, número de vagens por planta foram reduzidos de maneira geral conforme o atraso na época de piantio; a altura da inserção da $1^{\mathrm{a}}$ vagem aumentou com o atraso na época do plantio; 
c) a produção de grãos, sendo uma conseqüência do ciclo da planta, número de vagens por planta foram reduzidos de maneira geral conforme o atraso no plantio;

d) a melhor época de plantio foi a de $18 / 12$ que resultou em média de $1980,18 \mathrm{~kg} / \mathrm{ha}$;

e) a variedade Prata, dada a sua característi. ca agronômica, é mais suscetível à mancha púrpura;

f) Com base no presente ensaio, recomendamos para plantio de soja no Aripuanã: - a variedade Oriente, plantio feito no mês de dezembro, sendo a melhor produtividade no início da $2^{\mathrm{a}}$ quinzena de dezembro com $2795,72 \mathrm{~kg} / \mathrm{ha}$.

- a variedade Júpiter, plantio feito de dezembro à primeira quinzena de janeiro, sendo a melhor produção obtida no início da $2^{\text {a }}$ quinzena de dezembro com 2245,79 $\mathrm{kg} / \mathrm{ha}$.

- a variedade Pelicano, em caso de falta de sementes no mercado pode plantar-se no início da $2^{\mathrm{a}}$ quinzena de dezembro.

- a variedade Prata, não é recomendada pela sua baixa produtividade: é suscetível à doença.

\section{SUMMARY}

Four planting periods, spaced at 15 days intervals on December 4, were used in a field plot at the INPA-ARIPUANĀ Experiment Station - Mato Grosso do Norte with the object of studyng the effects of planting periods on several agronomic characteristics of the varieties "Jupiter", "Prata", "Oriente" and "Pelicano" during the farming season of $1976 / 77$. The split plot design was repented four times, using planting periods and varieties as main plot and sub-plots, respectively. The results obtained showed the following: With a delay in planting there is a decrease in the plant cycle. This is evident in the vegetative period and/or reproductive period. This is a consequence of photoperiod. Along with this decrease of plant cycle there is a decrease in plant height, stem diameter, number of pods per plant and an increase in first pod insertion. The variety "Jupiter" showed resistence to bacterial pusture (Xanthomonas phaseoli var, sojensis). The best planting date both varieties was December 18, which presented a yield of: "Oriente" $=2,795.83 \mathrm{~kg}$; "Jupiter" = 2,245.83 kg: "Pelicano" $=1,733.33 \mathrm{~kg}$ and "Prate" $=1,145,08 \mathrm{~kg} / \mathrm{ha}$. For the planting of soybean Aripuanã-MT, the variety "Oriente" in December and variety "Jupiter" in December until the middle of January are recommended. As this is a pioneer experiment in this region, the choosing of the planting period was dependent on climatic conditions of the region using varieties of various other that are less sensitive to the photoperiod.

\section{BIBLIOGRAFIA}

ABEL, JR, G.H.

1961 - Response of soybeans to dates of planting in the Imperial Valley of California. Agron. J., $53(1): 9598$.

Athon, K.L. \& SWEA, M.L.

1968 - Ensaio de épocas de plantio da soja em Viçosa, Instituto de Fitotecnia, ESA-UREMG, $2 p$.

BORTHWICK, H.A. \& PARKER, M.W.

1939 - Photoperíodic responses of general varieties of soybeans. Bot. Graz., 101: 341-365.

Bueno, L.C. de S.; Sedtyama, C.S. \& Vieira, C.

1975 - Efeito de espaçamento e densidade e época de plantio sobre duas variedades de soja. Experimentiae, 20(10) : 263-287.

CAMPER, H.M. \& SMITH, T.J.

1958 - The effect of date of planting, rate of planting, and width of row on two soybean varieties. Virginia Agr. Exp. Sta. Res. Rpt., 21.

Cowan, J.C.

1973 - Processing and Products in: Caldwell, B.E. ed. - Soybeans: Improvement, Production, and USES. American Society of Agronomy, p. 619-656.

FEASTER, C.V.

1949 - Influence of planting date on yield and other characteristics of soybeans grown in southern Missouri. Agron. J., 41(2) : 57-62.

GARNer, W.W. \& Allard, H.A.

1920 - Effect of the relative lenght of day and night and other factors of the environment on growth and reproduction in plants. Jour. Agr. Res., 18: 553-606.

1930 - Photoperiodic response of soybeans in relation to temperature and other environmental factors. J. Agr. Res., 41 : 719-735.

HaRTwig, E.E,

1954 - Factors affecting time planting soybeans in the Southern States. USDA Cir. 943.

LITZEMBERGER, S.C. (Ed.)

Guide for field crops in the tropos and the subtropos, p. 179-186.

Milanez, D.; Fonseca, W.F. \& Pacova, B.E.V.

1978 - Pesquisa e Experimentação com soja (Glycine max) (L) Merril no Estado do Espírito Santo. II Estudo de Época de Plantio. Re. vista CERES, 25(137) : 036-041. 
MIYASAKA, S.

1965 - Instruçōes para a cultura da soja. Bolm. Inst. Agron. Campinas, Săo Paulo, 122:1-20

OsLer, R.D. \& CARTTER, J.L.

1954 - Effect of planting date on chemical composition and growth characteristics of soybeans. Agron. Jour., 46: 267-269.

Rios, G.P.; Costaval, W.M. \& Sirva, T.

1971 - Época de plantio em soja Sete Lagoas, IPEACO, p. 2-3 Série Pesquisa Extensão Boletim, 7.

Santos, O.S. dos \& Pignataro, I.A.B.

1971 - Ensaio de variedades $X$ épocas de plantio de soja em Santa Maria, em 1S/7/1971. In: Reunião da Comissão Nacional de Soja, Curitiba.

Sediyama, T.; Andrade, D. \& Garcia, R.

1971 - Estudo de época de plantio da soja no Triângulo Mineiro, In. Dia de Campo no CEPET Capinópolis, 24 p.

Sediyama, T. \& Athow, K.L.

1971 - Soja; instruções para seu plantio Viçosa. Univ. F. Viçosa, 1p.

Sediyama, T.: Novais, R.F.; Milanez, D.; Fonseca, W.F. dA \& Sedryama, C.S.

1973 - A soja no Espírito Santo, Vitória, Secretaria da Agricultura do Espirito Santo, Boletim Técnico, 1: 36 .

SouZA, P.T. DE

1973 - Efeito de três épocas de semeadura no rendimento de grãos e caracteristicas agronô. micas de dois cultivos de soja (Glycine $\max (\mathrm{L})$ Merrill), Universidade Estadual de Rio Grande do Sul, Tese mestrado.
SOYBEAN MAgIL ...

s/d - The story of soybean processing. Leaflet by National Soybean Processors Association of the U.S.A

Torrie, J.H. \& Briggs, G.M.

1955 - Effect of planting date on yeld and other characteristics of soybeans. Agron. J., 47(5):210-212.

VERNETTI, F.J.

1956 - Cultura da soja Inst. Agron. Sul, Fio Grande do Sul.

VILJOEN, N.J.

1937 - An investigation into the composition of soybeans in South Africa. Dep. of B.gr. and For., Sci. Bul., 169.

Weiss, M.G.; Weber, C.R.; Williams, L.F. \& Probst, A.A.

1950 - Variability of agronomic and seed compositional characters in soybeans as influenced by variet and time of planting. U.S.D.A. Thech. Bull., 1017.

YuYAMA, K.

1976 - Efeito de épocas de plantio, sobre várias características agronômicas na cultura de soja (Glycine max (L) Merrill), variedades "Santa Rosa" e "Vicoja" em Jaboticabal, S.P. Trabalho Apres, à Faculdade de Medicina Veterinária, Agronomia e Zootecnia de Jaboticabal, para graduação em Agronomia - UNESP.

(Aceito para publicação em 29/01/79) 